\title{
PENGELOLAAN LAHAN AKRESI DESA PAMBANG PESISIR, PULAU BENGKALIS, PROVINSI RIAU
}

\author{
Miswadi $^{*}$, Romie Jhonnerie ${ }^{2}$, Eko Prianto ${ }^{3}$ \\ ${ }^{1}$ Mangrove Research Institute (MRI) \\ ${ }^{2,3}$ Fakultas Perikanan dan Ilmu Kelautan, Universitas Riau \\ *Koresponden E-mail: miswapratama@gmail.com
}

\begin{abstract}
The breakwater construction to overcome abrasion at Pambang Pesisir has resulted in the formation of land accretion, which expanded the coastal land and giving rises to issues in public management. This research was aimed to formulate the alternative management of land accretion. A field survey and light unmanned aerial vehicle (drone) data acquisition were used to observe the accretion formed. Furthermore, Analytical Hierarchy Process (AHP) was used to generate the alternative managements of land accretion. The accretion land was estimated around 80,359.4 m2and based on coastal area protection, living creature's habitat, fisheries resources, tourism and business development benefit, social community supporting and sustainability of social interaction criteria's, this area had great potential to be managed with use it for mangrove planting or rehabilitation sites in ecological land-based management.
\end{abstract}

\section{Keywords: AHP, Accression, Management, Pambang Pesisir}

Pantai Desa Pambang Pesisir membentang di pesisir Pulau Bengkalis dari bagian Selatan (berbatas dengan Desa Pambang Baru atau Teluk Pambang, Tanjung Senekip) hingga bagian Utara (berbatas dengan Desa Pambang Baru/Muntai, Tanjung Parit). Wilayah pantai di Desa Pambang Pesisir dimanfaatkan sebagai permukiman penduduk dan juga merupakan salah satu tujuan masyarakat untuk menikmati nuansa pantai. Terbentuknya lahan akresi di wilayah ini tidak terlepas dari bencana abrasi sebelumnya di garis pantai desa ini (Gambar 1). Abrasi menjadi ancaman serius karena mengakibatkan hilangnya lahan pesisir sehingga salah satu upaya yang dilakukan untuk menanggulanginya dengan membangun konstruksi turap pantai. Rangel-Buitrago et al. (2018) menyatakan bahwa perlindungan pesisir dengan struktur konstruksi buatan (hard structure) menjadi satu-satunya strategi untuk masalah abrasi (coastal erosion) seperti sea wall dan breakwater terutama di kawasan wisata.

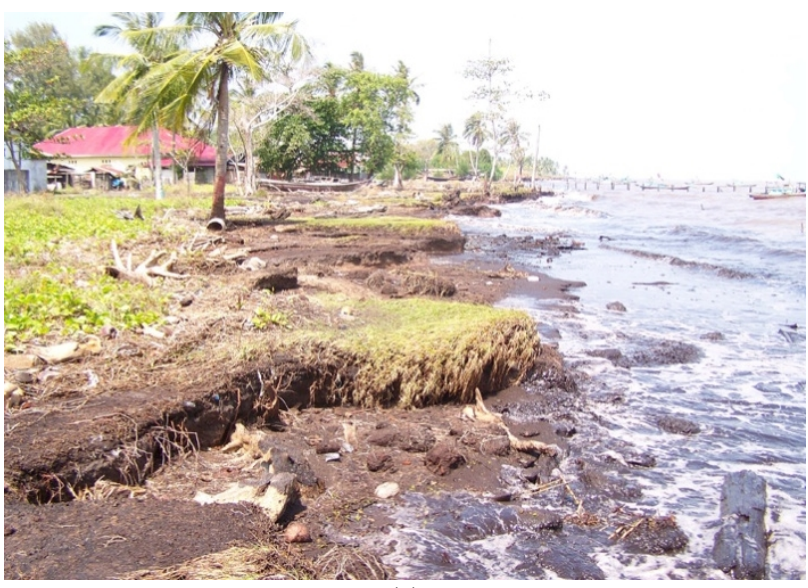

(a)

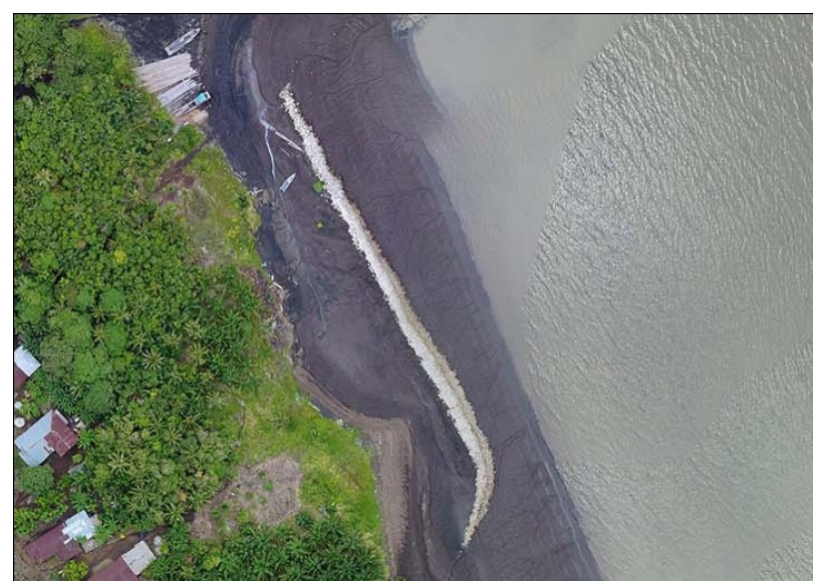

(b)

Gambar 1. (a) Kondisi abrasi di pantai Pambang Pesisir sebelum ada penanganan turap pantai (Sumber Foto: Yayasan Laksana Samudera, 2008). (b) Kawasan pantai Pambang Pesisir yang telah dibangun turap pantai dan memperangkap sedimen

Turap pantai di wilayah ini dibangun tepat berada di bibir pantai. Kejadian tidak sengaja terhadap pergeseran letak turap menjadi ide bagi masyarakat untuk meneruskan pembangunan turap menjadi pemecah ombak (breakwater) yang dibangun agak jauh dari bibir pantai. Sedimen mulai terperangkap dan membentuk daratan dalam rentang waktu lima tahun usia kontruksi tersebut (Gambar 1). Menurut Neelamani (2018) bahwa adanya infrastruktur perlindung pantai telah berpengaruh terhadap terjadinya abrasi dan akresi. Terjadinya akresi (sedimentasi) di satu bagian sisi lain pantai, terjadi pula abrasi di bagian sisi pantai lainnya.

Rangel-Buitrago et al. (2018) dan Martinez et al. (2018) menyebutkan bahwa kerusakan ekosistem, ketidakseimbangan sedimen, gelombang ekstrim dan kenaikan muka air laut merupakan faktor yang mempengaruhi terjadinya abrasi (coastal erosion). Shi et al. (2016) menjelaskan bahwa konsentrasi sedimen tersuspensi pada lumpur pasang surut berpengaruh terhadap lingkungan ekologis dan evolusi morfologi pantai. Proses angkutan sedimen tersuspensi 
mendukung interpretasi perubahan morfologi pada lumpur intertidal akresi. Hal ini dipengaruhi oleh faktor hidrodinamika (kedalaman air, angin, tinggi gelombang, kecepatan arus) dan faktor lingkungan (salinitas dan suhu).

Terbentuknya lahan akresi memunculkan ide masyarakat untuk mengelolanya. Adanya perbedaan pendapat di masyarakat untuk mengelola lahan tersebut sehingga penting untuk menemukan alternatif solusi yang mempertimbangkan berbagai kriteria pengelolaan untuk merumuskan pengelolaan yang tepat terhadap lahan tersebut.

\section{BAHAN DAN METODE}

Penelitian ini dilakukan selama bulan Agustus 2017 di Desa Pambang Pesisir, Kecamatan Bantan, Kabupaten Bengkalis yang secara geografis terletak di Pulau Bengkalis Provinsi Riau (Gambar 2) sebagai salah satu pulau terluar Indonesia di bagian timur Pulau Sumatera. Metode yang digunakan dalam penelitian ini adalah metode survei dengan melakukan observasi terhadap kondisi lahan akresi Desa Pambang Pesisir dan isu pengelolaannya serta analisis citra perekaman pesawat tanpa awak. Data primer dikumpulkan melalui diskusi secara brainstorming dan menyebarkan kuisioner pada responden.

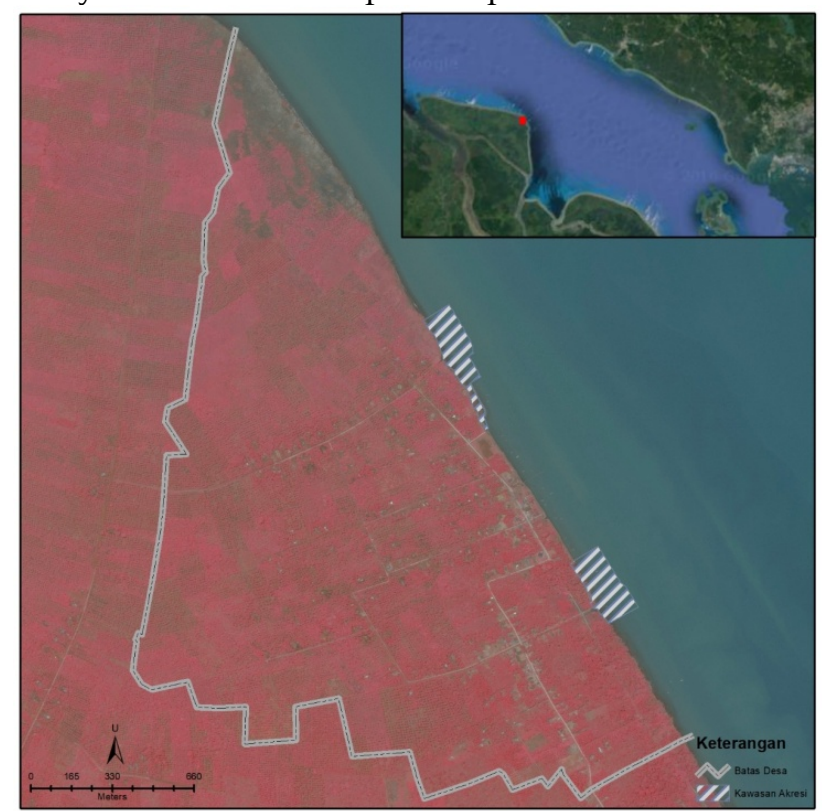

Gambar 2. Peta Desa Pambang Pesisir dan titik lokasi lahan akresi yang terbentuk
Penentuan responden dilakukan secara purposive. Menurut Sudaryono (2017), dalam purpossive sampling, pemilihan responden bertitik tolak pada penelitian pribadi peneliti bahwa responden yang dipilih benar-benar representatif dengan membuat kriteria tertentu terhadap responden dan peneliti memiliki pengetahuan yang memadai tentang karakteristik populasi. Jumlah responden dalam purpossive sampling tidak ditentukan secara statistik, hanya berdasarkan kepentingan peneliti. Kriteria responden yang dibangun meliputi: masyarakat Desa Pambang Pesisir, berusia $\geq 30$ tahun (atau sudah menikah), terlibat dalam kelembagaan masyarakat maupun pemerintah desa, memiliki pengetahuan terhadap topik masalah penelitian, memiliki kepentingan dalam pembangunan desa, bersedia dan dapat memberikan pendapat. Dari kriteria tersebut maka responden yang dipilih, yaitu: perangkat desa, tokoh masyarakat, tokoh perempuan, tokoh pemuda, pengurus kelompok nelayan dan koperasi perikanan serta kelompok swadaya masyarakat lainnya di desa. Besaran sampel yang digunakan sebanyak 25 responden.

\section{Analytical Hierarchy Process (AHP)}

Analytical Hierarchy Process (AHP) merupakan salah satu metode untuk membantu menyusun suatu prioritas dari berbagai pilihan dengan menggunakan beberapa kriteria (multi criteria) dan didasarkan pada suatu proses yang terstruktur dan logis (Susila et al., 2007). Menurut Saaty (2008), struktur hirarki dalam AHP tersusun atas tingkatan yang merupakan hirarki atas unsur-unsur diatasnya, meliputi: tujuan, kriteria dan alternatif. Penggunaan prinsip kerja AHP melalui perbandingan berpasangan (pairwise comparisons) sehingga tingkat kepentingan suatu kriteria relatif terhadap kriteria lainnya dapat dinyatakan dengan jelas. Perbandingan didasarkan "judgement" dari pengambil keputusan dengan menilai tingkat kepentingan suatu elemen dibandingkan elemen lainnya. Analisis ini menghasilkan perbandingan: (a) bobot kriteria terhadap tujuan yang menunjukkan keunggulan masing-masing kriteria dalam pencapaian tujuan, (b) bobot agregat alternatif yang menunjukkan preferensi masing-masing alternatif strategi, dan (c) ringkasan detil bobot agregat alternatif yang memperlihatkan keunggulan masing-masing kriteria dalam masing-masing alternatif strategi. Dari kriteria dan alternatif strategi dalam penelitian ini dibentuk hirarki permasalahan dalam menentukan pemilihan arah pengelolaan 


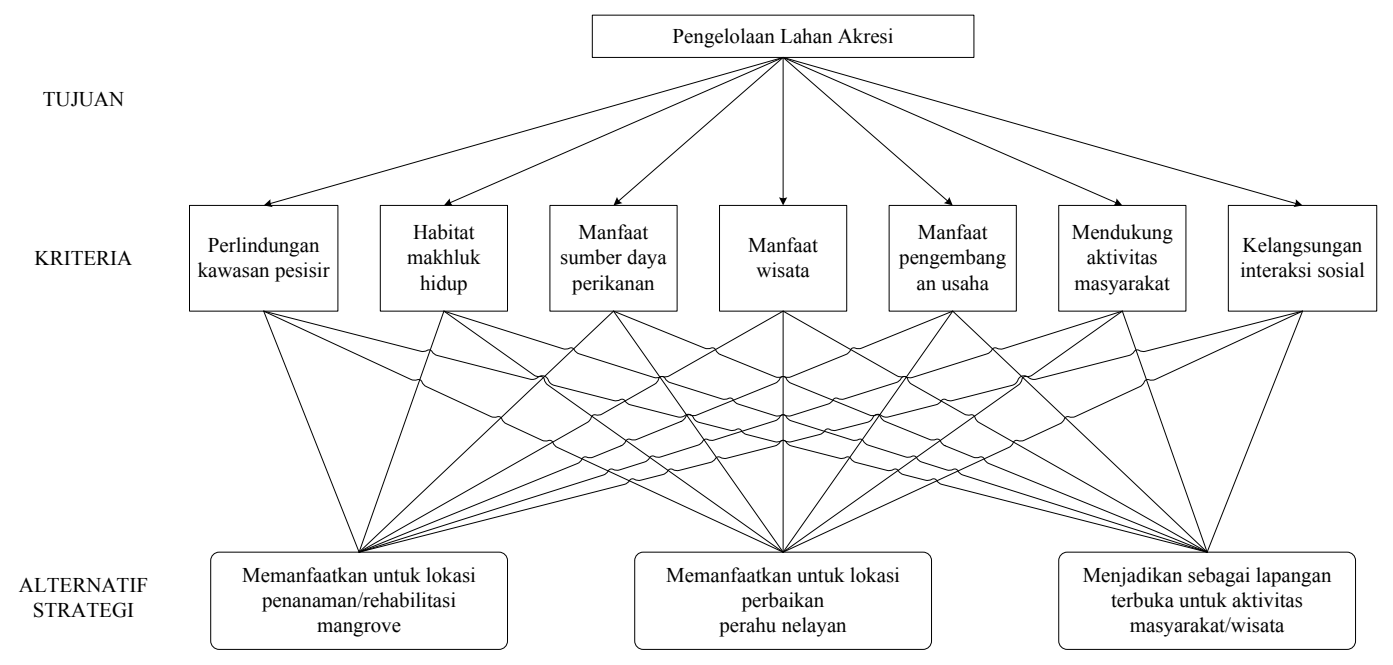

Gambar 3. Hirarki permasalahan pengelolaan lahan akresi

Terdapat tujuh kriteria dan tiga alternatif strategi dalam pengelolaan lahan akresi pada penelitian ini. Kriteria dimaksud terdiri dari: 1) perlindungan kawasan pesisir, 2) habitat makhluk hidup, 3) manfaat sumber daya perikanan, 4) manfaat wisata, 5) manfaat pengembangan usaha, 6) mendukung aktivitas masyarakat dan 7) keberlangsungan interaksi sosial. Alternatif strategi pengelolaan lahan akresi, meliputi: 1) memanfaatkan untuk lokasi penanaman/rehabilitasi mangrove, 2) memanfaatkan untuk lokasi perbaikan perahu nelayan, dan 3) menjadikan sebagai lapangan terbuka untuk aktivitas masyarakat/wisata. Pengembangan alternatif pengelolaan menggunakan AHP dengan taraf ketidak konsistenan yang dapat diterima (inconsistency) $\leq 0,10$ untuk mencapai tujuan (Saaty, 2008).

\section{HASIL}

\section{Luas dan kondisi lahan akresi}

Desa Pambang Pesisir memiliki panjang pantai sepanjang $3500 \mathrm{~m}$. Wilayah ini merupakan pantai terbuka sehingga sangat rentan dalam menerima hempasan gelombang. Menurut Hariyoni et al. (2013) bahwa kondisi pantai yang terbuka mengakibatkan terjadinya serangan gelombang dari berbagai arah. Struktur tanah yang labil di wilayah desa ini sehingga tanah sepanjang garis pantai ringkih akibat hempasan gelombang dan tidak jarang dijumpai rekahanrekahan. Rekahan-rekahan tanah tersebut rentan terjadi abrasi apabila tidak dihalangi dengan konstruksi buatan.

Pembangunan turap berupaya menekan laju abrasi. Turap pantai yang dibangun awalnya adalah sebagai sea wall (penahan bibir pantai) kemudian dilanjutkan dengan membangun breakwater. Adanya breakwater telah memperangkap sedimen di dua lokasi breakwater (bagian utara dan selatan) sehingga membentuk daratan dan menjadi hamparan lahan. Dari analisis Citra perekaman pesawat tanpa awak terhadap kondisi lahan akresi yang terbentuk, diketahui bahwa lahan akresi yang terbentuk seluas $80.359,4 \mathrm{~m} 2$. Saat ini, lahan tersebut tengah dimanfaatkan sebagai aktivitas docking perahu motor nelayan untuk perbaikan perahu motor tersebut.

\section{Isu pengelolaan dan faktor kepentingan}

Pengelolaan lahan akresi di Desa Pambang Pesisir memperhatikan tiga aspek penting, yaitu ekologi, ekonomi dan sosial. Aspek ekologi, abrasi yang terjadi di wilayah pesisir desa ini telah menghilangkan lahan masyarakat dan mengakibatkan kerusakan pantai. Pembangunan turap pantai adalah untuk melindungi wilayah pesisir desa dari terjadinya abrasi. Abrasi juga telah sejak lama menghilangkan hutan mangrove yang menjadi habitat berbagai makhluk hidup di wilayah pesisir desa ini.

Aspek ekonomi, mangrove adalah sumber daya pesisir yang mampu memberikan manfaat terhadap sumber daya perikanan dan pekerjaan utama masyarakat desa ini umumnya nelayan. Perikanan tangkap menjadi andalan dalam menopang hidup masyarakat di wilayah ini sehingga dukungan terhadap keberlanjutan sumber daya perikanan sangat diperlukan untuk keberlanjutan ekonomi masyarakat desa ini. Upaya memberikan manfaat ekonomi dan pengembangan usaha alternatif bagi masyarakat telah pula dilakukan Pemerintah Kabupaten Bengkalis dengan menjadikan wilayah pantai di desa ini menjadi tujuan wisata. Infrastuktur pendukung wisata yang telah dibangun seperti gazebo, toilet umum dan aula peristirahatan.

Aspek sosial, wilayah pesisir mendukung berlangsungnya aktivitas dan interaksi sosial masyarakat. Terjadinya abrasi memberikan dampak mengurangi luasan lahan pesisir dan mempengaruhi aktivitas masyarakat. Salah satu kasus terjadinya abrasi yang cukup parah adalah di Desa Bedono Kabupaten Demak Provinsi Jawa Tengah yang telah menyebabkan permukiman berpindah bahkan hilang sehingga interaksi sosial masyarakat terganggu. Desa ini adalah desa yang terkena abrasi paling besar di 
Kabupaten Demak. Luas lahan desa 739,2 ha (1997) laut (Damaywanti, 2013). Oleh karenanya,

\begin{tabular}{lllll}
\hline No Kriteria/Sub Kriteria & & \multicolumn{1}{c}{ Prioritas } \\
\hline dan tersisa 551,673 ha & (2012). & Dinamika & pemanfaatan lahan akresi di Desa Pambang Pesisir \\
kependudukannya cenderung mengalami penurunan & diarahkan untuk mendukung berlangsungnya aktivitas \\
jumlah karena penduduk desa direlokasi atau & dan interaksi sosial. Isu pengelolaan lahan akresi di \\
berpindah. Tercatat 972 penduduk tahun 2010 & Desa Pambang Pesisir dan faktor kepentingannya \\
meninggalkan desa akibat rumah dan lahan tempat & disajikan pada Tabel 1.
\end{tabular}

tinggalnya terkena dampak abrasi sehingga menjadi

Tabel 1. Isu pengelolaan lahan akresi di Desa Pambang Pesisir

\begin{tabular}{ll}
\hline Isu Pengelolaan & Faktor Kepentingan \\
\hline 1. Memanfaatkan untuk lokasi & 1. Perlindungan kawasan pesisir \\
penanaman/rehabilitasi mangrove & 2. Mendukung habitat makhluk hidup \\
2. Memanfaatkan untuk lokasi perbaikan perahu & 3. Memberikan manfaat terhadap sumber daya perikanan \\
nelayan & 4. Memberikan manfaat wisata \\
3. Menjadikan sebagai lapangan terbuka untuk & 5. Memberikan manfaat bagi pengembangan usaha \\
aktivitas masyarakat/wisata & 6. Mendukung aktivitas masyarakat \\
& 7. Mendukung keberlangsungan interaksi sosial \\
\hline
\end{tabular}

Pemanfaatan lahan akresi yang terbentuk di kawasan pesisir desa ini dipertimbangkan menjadi fungsi untuk perlindungan pesisir, menjadi tempat hidup berbagai jenis biota dan hewan lain yang berasosiasi dengannya, mampu memberikan manfaat terhadap sumber daya perikanan, mampu memberikan manfaat terhadap pengembangan wisata, usaha masyarakat berdasarkan potensi usaha yang tersedia dan keberlangsungan interaksi sosial. Isu pengelolaan menjadi alternatif strategi dalam pengelolaan lahan akresi sedangkan faktor-faktor kepentingan yang mesti diperhatikan dalam mengelola isu pengelolaan terhadap pemanfaatan lahan akresi ditentukan sebagai kriteria yang disusun secara hirarki dan dianalisis berdasarkan tingkat kepentingannya.

\section{Arah pengelolaan}

Hasil analisis AHP diperoleh pembobotan kriteria terhadap tujuan yang menunjukkan bobot tertinggi adalah kriteria perlindungan kawasan pesisir sebesar 0,300 dan diikuti oleh kriteria manfaat sumber daya perikanan sebesar 0,163 . Besar bobot masingmasing kriteria disajikan pada Gambar 4.

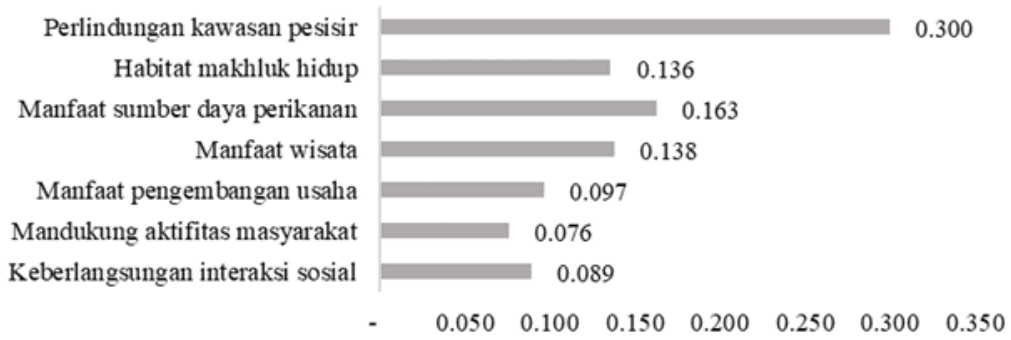

Gambar 4. Bobot kriteria terhadap tujuan: pengelolaan lahan akresi

Besarnya bobot kriteria perlindungan kawasan pesisir dan manfaat sumber daya perikanan menunjukkan bahwa keduanya adalah kriteria terpenting dalam arah pengelolaan lahan akresi sebagai tujuan strategi. Untuk pembobotan agregat (keseluruhan) alternatif menunjukkan bahwa pengelolaan lahan akresi di Desa Pambang Pesisir memiliki potensi lebih besar dimanfaatkan untuk lokasi penanaman/ rehabilitasi mangrove (Alternatif 1) dari pada memanfaatkan untuk lokasi perbaikan perahu nelayan (Alternatif 2) dan menjadikan sebagai lapangan terbuka untuk aktivitas masyarakat/wisata (Alternatif 3). Hasil pembobotan agregat alternatif ditampilkan pada Gambar 5.

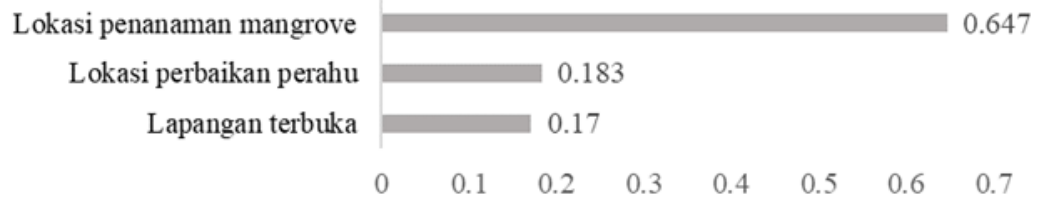

Gambar 5. Bobot agregat alternatif pengelolaan lahan akresi

Pembobotan agregat alternatif tersebut memperlihatkan penilaian Alternatif $1(0,647)$ lebih besar dari Alternatif $2(0,183)$ dan Alternatif $3(0,170)$. Dalam hal ini Alternatif 1 mempunyai preferensi lebih baik dari pada Alternatif 2 dan Alternatif 3 terhadap semua kriteria yang ada. Penilaian tersebut dirinci melalui Tabel 2. 


\begin{tabular}{llllll}
\hline & & Alt. 1 & Alt. 2 & Alt. 2 & 0,034 \\
1. & Perlindungan kawasan pesisir & 0,194 & 0,042 & 0,270 & 0,145 \\
2. & Habitat makhluk hidup & 0,088 & 0,028 & 0,029 & 0,156 \\
3. & Manfaat sumber daya perikanan & 0,106 & 0,026 & 0,024 & 0,119 \\
4. & Manfaat wisata & 0,089 & 0,015 & 0,015 & 0,022 \\
5. & Manfaat pengembangan usaha & 0,063 & 0,032 & 0,117 \\
6. & Mendukung aktivitas masyarakat & 0,049 & 0,013 & 0,015 & 0,077 \\
7. & Kelangsungan interaksi sosial & 0,058 & 0,027 & 0,031 & 0,116 \\
& Total & 0,647 & 0,183 & 0,170 & 1,000 \\
\hline
\end{tabular}

Tabel 2. Ringkasan detail sintesa pengelolaan lahan akresi

Keterangan: Inconsistency 0,06; Alt. 1 : Memanfaatkan untuk lokasi penanaman/rehabilitasi mangrove; Alt. 2 : Memanfaatkan untuk lokasi perbaikan perahu nelayan; Alt. 3 : Menjadikan sebagai lapangan terbuka untuk aktivitas masyarakat/wisata

Secara hirarki, strategi pengelolaan lahan akresi di Desa Pambang Pesisir dengan memanfaatkannya untuk lokasi penanaman/rehabilitasi mangrove adalah untuk perlindungan kawasan pesisir, mendukung habitat makhluk hidup, memberikan manfaat terhadap sumber daya perikanan, manfaat wisata, manfaat bagi pengembangan usaha, mendukung aktivitas masyarakat dan keberlangsungan interaksi sosial.

\section{PEMBAHASAN}

Salah satu upaya untuk mengatasi permasalahan kerusakan wilayah pesisir pantai adalah dengan penanaman mangrove di sepanjang pesisir pantai. Mangrove sangat bermanfaat baik fisik, ekologis, sosial dan ekonomi bagi kawasan pesisir dan mesyarakat penghuni kawasan tersebut (Muharram, 2014). Penanaman mangrove di wilayah yang memiliki tingkat abrasi tinggi akan gagal selama penyebab utamanya belum teratasi. Pembuatan tanggul pemecah gelombang terbukti efektif mewujudkan keberhasilan penanaman mangrove sehingga mampu mengurangi efek abrasi (Setyawan et al. 2004). Lemahnya tekanan arus dan gelombang karena adanya konstruksi pemecah gelombang di Desa Pambang Pesisir mengakibatkan terjadinya sedimentasi sehingga membuat terbentuknya lahan akresi. Hal ini memungkinkan untuk dilakukannya penanaman mangrove di wilayah tersebut.

Arahan pengelolaan lahan akresi di Desa Pambang Pesisir adalah memanfaatkan untuk lokasi penanaman atau rehabilitasi mangrove. Hal ini dengan mempertimbangkan ketujuh kriteria pengelolaan. Menurut WaltersBradley et al. (2008) dan Nagelkerken et al. (2008), hutan mangrove merupakan ekosistem yang memiliki fungsi penting secara ekologis. Lacerda (2002) menyatakan bahwa secara ekologis, fungsi dan manfaat hutan mangrove adalah sebagai kawasan penyangga proses terjadinya intrusi atau penahan laju intrusi air laut, sebagai penahan gelombang, pencegah abrasi dan sebagai perangkap sedimen maupun penahan angin badai.

WaltersBradley et al. (2008) dan Tampubolon (2008) menyatakan bahwa mangrove telah memberikan manfaat besar baik langsung maupun tidak langsung. Menurut Lacerda (2002), fungsi dan manfaat hutan mangrove diantaranya sebagai kawasan untuk berlindung, sebagai tempat bersarangnya burung yang menghasilkan telur, bersarang dan berkembang biak bagi berbagai biota air, sebagai daerah asuhan (nursery ground), mencari makan (feeding ground) dan daerah pemijahan (spawning ground) bagi berbagai macam biota perairan khususnya ikan. Daya dukung ekosistem hutan mangrove terhadap biota perairan secara khusus ditunjukkan dari nilai produktivitas primer sehingga dapat menentukan stok ikan di perairan. Pada luasan mangrove 146 hektar, maka produksi ikan yang disumbangkan oleh ekosistem mangrove adalah 192,2 ton per tahun. Osmaleli et al. (2014) menyatakan bahwa kelestarian sumber daya udang sangat tergantung dengan kelestarian mangrove. Keterkaitan ekosistem mangrove dengan udang dilihat dari marginal produktivitas dari mangrove area sebesar 153,454 ton per $\mathrm{km} 2$ dan 0,305 ton per trip hasil tangkapan kapal jaring udang.

Di lain sisi, pengelolaan bentang alam hutan mangrove dapat berkembang untuk kegiatan wisata (Sawitri et al. 2013; Wijayanto et al. 2013). Berarti kedepannya mangrove yang berkembang dapat mendukung berkembangnya destinasi wisata di wilayah pesisir Desa Pambang Pesisir. Umam et al. (2015) menyatakan bahwa manfaat yang dapat diperoleh masyarakat dengan adanya pembangunan wisata mangrove antara lain memberikan kenyamanan beraktivitas, kondisi lingkungan yang semakin membaik, dan terciptanya lapangan pekerjaan dan kesempatan berusaha.

Dalam pengelolaan lahan pesisir untuk rehabilitasi mangrove, diarahkan mampu berdampak positif terhadap aktivitas dan kelangsungan interaksi sosial masyarakat. Terjaganya wilayah pesisir dari ancaman abrasi dan terehabilitasinya fungsi hutan mangrove dapat memberikan kesempatan berusaha dan peluang ekonomi bagi masyarakat pesisir sehingga masyarakat dapat beraktivitas dengan layak dan interaksi sosial masyarakat dapat berlangsung dengan baik. Susilo (2009) menyatakan bahwa hubungan manusia berlangsung dalam komunitas ekologis, hubungan antar manusia dapat berlangsung dengan baik dalam kondisi lingkungan yang mampu mendukung kelangsungan hidup manusia. Kecukupan ruang di wilayah pesisir dapat bermanfaat untuk beragam aktivitas masyarakat seperti bermain, berolah raga, mengembangkan usaha dan untuk berbagai aktivitas masyarakat lainnya. Menurut Budihardjo dan Sujarto (2005), adanya ruang terbuka sebenarnya 
merupakan wadah yang dapat menampung aktivitas tertentu dari masyarakat di wilayah tersebut, karena di dalam ruang terbuka ini berbagai manusia dengan berbagai aktivitas dapat bertemu.

\section{SIMPULAN}

Lahan akresi di Desa Pambang Pesisir Kecamatan Bantan Kabupaten Bengkalis seluas $80.359,4 \mathrm{~m} 2$ berdasarkan kriteria perlindungan kawasan pesisir, habitat makhluk hidup, manfaat sumber daya perikanan, manfaat wisata, manfaat pengembangan usaha, mendukung aktivitas masyarakat dan keberlangsungan interaksi sosial memiliki potensi besar untuk dikelola dengan memanfaatkannya untuk lokasi penanaman atau rehabilitasi mangrove dalam upaya pengelolaan lahan berbasis ekologi.

\section{UCAPAN TERIMA KASIH}

Penulis menyampaikan terima kasih kepada Perangkat Desa Pambang Pesisir Kecamatan Bantan Kabupaten Bengkalis dan warga yang turut membantu selama penelitian. Selanjutnya ucapan terima kasih juga disampaikan kepada seluruh pihak yang membantu dalam kelancaran penelitian ini.

\section{DAFTAR PUSTAKA}

Budiharjo, E. dan D. Sujarto. 2005. Kota Berkelanjutan. Alumni, Bandung.

Damaywanti, K. 2013. Dampak Abrasi Pantai terhadap Lingkungan Sosial (Studi Kasus di Desa Bedono, Sayung, Demak). Prosiding Seminar Nasional Pengelolaan Sumber daya Alam dan Lingkungan (Optimasi Pengelolaan Sumber daya Alam dan Lingkungan dalam Mewujudkan Pembangunan Berkelanjutan). (Semarang, 10 September 2013). Hal. 363-367. Himpunan Mahasiswa Doktor dan Magister Ilmu Lingkungan Universitas Diponegoro, Semarang.

Hariyoni, D. Sisinggih dan S. Marsudi. 2013. Studi Perencanaan Bangunan Pengendalian Akresi dan Abrasi di Pantai Tanjungwangi Kabupaten Banyuwangi. Jurnal Teknik Pengairan, 4(1): 20-29.

Lacerda, L.D. 2002. Mangrove Ecosystems: Function and Management. Springer-Verlag Berlin Heidelberg, New York.

Martínez, C., M. Contreras-Lopez, P. Winckler, H. Hidalgo, E. Godoy, E. and R. Agredano. 2018. Coastal Erosion in Central Chile: A New Hazard?. Journal of Ocean and Coastal Management, 156: 141-155.

Muharram. 2014. Penanaman Mangrove sebagai Salah Satu Upaya Rehabilitasi Lahan dan Lingkungan di Kawasan Pesisir Pantai Utara Kabupaten Karawang. Jurnal Ilmiah Solusi, 1(1): 1-14.
Nagelkerken, I., S.J.M. Blaber, S. Bouillon, P. Green, M. Haywood, L.G. Kirton, J.O. Meynecke, J. Pawlik, H.M. Penrose, A. Sasekumar and P.J. Somerfield. 2008. The Habitat Function of Mangrove for Terrestrial and Marine Fauna: A Review. Aquatic Botany, 89: 155-185.

Neelamani, S. 2018. Coastal Erosion and Accretion in Kuwait: Problems and Management Strategies. Journal of Ocean and Coastal Management, 156: 76-91.

Osmaleli, T. Kusumastanto dan M. Ekayani. 2014. Analisis Ekonomi Keterkaitan Ekosistem Mangrove dengan Sumber Daya Udang (Studi Kasus: Desa Pabean Udik, Kecamatan Indramayu). Journal of Agriculture, Resource, and Environmental Economics, 1: 61-70.

Rangel-Buitrago, N., A. Williams and G. Anfuso. 2018. Hard Protection Structures as a Principal Coastal Erosion Management Strategy Along The Caribbean Coast of Colombia: A Chronicle of Pitfalls. Journal of Ocean and Coastal Management, 156: 58-75.

Saaty, T.L. 2008. Decision Making with the Analytic Hierarchy Process. International Journal Services Sciences, 1(1): 83-98.

Sawitri, R., M. Bismark dan E. Karlina. 2013. Ekosistem Mangrove sebagai Obyek Wisata Alam di Kawasan Konservasi Mangrove dan Bekantan di Kota Tarakan. Jurnal Penelitian Hutan dan Konservasi Alam, 10(3): 297-314.

Setyawan, A.D., K. Winarno dan P.C. Purnama. 2004. Ekosistem Mangrove di Jawa: Restorasi. Biodiversitas. 5(2): 105-118.

Shi, B., Y.P. Wang, X. Du, J.R. Cooper, P. Li, M.L. Li and Y. Yang. 2016. Field and Theoretical Investigation of Sediment Mass Fuxes on an Accretional Coastal Mudflat. Journal of Hydro-environment Research, 11: 75-90.

Sudaryono. 2017. Metodologi Penelitian. Rajawali Pers, Jakarta.

Susila, R. Wayan dan E. Munadi. 2007. Penggunaan Analytical Hierarchy Process untuk Penyusunan Prioritas Proposal Penelitian. Jurnal Informatika Pertanian, 16(2): 983-998.

Susilo, D.R.K. 2009. Sosiologi Lingkungan. Rajawali Pers, Jakarta.

Tampubolon, A.P. 2008. Kajian Kebijakan Energi Kayu Bakar. Jurnal Analisis Kebijakan Kehutanan, 5(1): 29-37.

Umam, K., Sudiyarto, S.T. Winarno. 2015. Strategi Pengembangan Ekowisata Mangrove Wonorejo, Surabaya. Jurnal Agraris, 1(1): 3842.

Walters Bradley, B., P. Ronnback, J.M. Kovacs, B. Crona, S.A. Hussain, R. Badola, J.H. Primavera, E. Barbier and F. DahdouhGuebas. 2008. Ethnobiology, Socioeconomics and Management of Mangrove Forests: A Review. Journal of Aquatic Botany, 89: 220236.

Wijayanto, D., D.M. Nuriasih, M.N. Huda dan C.R.K. Pamuntjak. 2013. Strategi 
Miswadi, Romie Jhonnerie, Eko Prianto | DLI 7 (1) (2020) 1-7 7

Pengembangan Pariwisata Mangrove di Kawasan Konservasi Perairan Nusa Penida. Jurnal Saintek Perikanan, 8(2): 25-32. 